\title{
The Resistance to the Action of Molds of Some Painting Materials Aged by Thermal Cycling and Exposed to an Electrical Field of $50 \mathrm{~Hz}$
}

\begin{abstract}
ALINA CARAMITU1', NICOLETA BUTOI ${ }^{1}$, TRAIAN RUS ${ }^{2}$, ANA MARIA LUCHIAN ${ }^{1 *}$, SORINA MITREA ${ }^{1}$
${ }^{1}$ National Institute for Research and Development in Electrical Engineering INCDIE ICPE-CA , 313, Splaiul Unirii, Bucharest, Romania,

2University Politehnica of Bucharest, Faculty of Applied Chemistry and Materials Science, 313 Splaiul Independentei, Bucharest, Romania

In order to evaluate the durability of paint layers exposed to simultaneous action of climatic and electrical stresses, the influence of $50 \mathrm{~Hz}$ electrical field and of aging by thermal cycling on the resistance to the action of molds of some painting materials was evaluated by specific microbiological determinations. Comparative measurements were carried out on initial paint samples and samples aged by applying of 1000 successive thermal cycles (between $-38^{\circ} \mathrm{C}$ and $85^{\circ} \mathrm{C}$, with the duration of a cycle of $90 \mathrm{~min}$ ), exposed to Czapek-Dox culture media (with and without sucrose), inoculated with a salt solution containing approximately $10^{6}$ mold spores (of 10 different species), and incubated at $30 \pm 2{ }^{\circ} \mathrm{C}$ and $\mathrm{RH} 90 \pm 5 \%$. It was found that for the samples exposed to a controlled field of $5 \mathrm{~V} / \mathrm{cm}$ and $50 \mathrm{~Hz}$ the resistance to the action of molds is almost two times less than in the absence of the disruptive electric field. Also, it was noticed that the field of $5 \mathrm{~V} / \mathrm{cm}$ and $5 \mathrm{HHz}$ stimulates the growth of Aspergillus niger, but completely inhibit those of Trichoderma viride and Aspergillus flavus.
\end{abstract}

Key words: painting materials, epoxy resins, polyurethane resins, thermal aging, molds, biodeterioration

The durability and the safety in exploitation of various metallic structures protected against corrosion by painting is a complex problem with special practical and economic implications.

The complexity of this issue is given both by the diversity of metallic structures and paints and by the great diversity of the stress factors acting on them. During operation, the painted metallic structures can be exposed simultaneously to mechanical stress (vibration, wind, etc.), climatic influences (humidity, diurnal temperature variations, frost deposits, etc.), pollutants and atmospheric aggressive substances $\left(\mathrm{SO}_{2}, \mathrm{NO}, \mathrm{CO}_{2}\right.$, aerosols- marine climate, powders, etc.), $U V$ and IR radiations, microbiological factors, etc. Under the concentrated action of the stress factors, often with synergistic complex effects, the paint layers deteriorate and initiate complex metal corrosion processes.

As a result of metallic support corrosion, the mechanical strength of the structure decreases, which can conduct to the compromise of the structure under extreme solicitations, with the corresponding economic, ecological and social complications. Thus, in the case of supporting pillars of the power lines especially those in alpine areas (exposed to intense UV radiation), but also those on the seashore (exposed to marine climate) after excessive aging of the paint layers and metal corrosion there is a risk of both tearing down the pillars and leakage of the corrosion products on the insulators for supporting the conductors; in both cases an interruption of electricity supply occurs $[1,2]$.

Basically, the polymeric material presents a good resistance to the action of microorganisms due to high molecular weight and volume [3-5]. Biodeterioration and biodegradation of polymers occur only after the result of aging processes. Under the action of atmospheric stress factors [6, 7], UV radiation [ 8,9$]$ and / or mechanical stress [10], the polymer chain is fractionated molecularly and the molecular mass and volume decrease [11, 12]. Under the action of the enzymatic activity of microorganisms [13], the carbon metabolization from the resin becomes possible. Thus, by laboratory experimental studies [3-5, 14] and by landfield investigations [2] the biodeterioration of the polymers exposed to atmospheric and to soil stressors was reported [15-19].

As a result of the excessive industrialization and of the continuous increase in production and consumption of electrical energy, the electromagnetic pollution of the environment with disturbing signals coming both from transport and distribution lines, as well as from different consumers that generate deforming regime [20] and/or of electromagnetic waves is becoming more pronounced [21]. The anthropogenic electromagnetic fields accelerate the natural processes of corrosion [22-24] and produce changes in metabolism, the growth and the reproduction of microorganisms [25-29]. On the other hand, various studies report the increase of the corrosion rate of the general purpose metals in the presence of microorganisms [30-34], an increase that is more pronounced (synergistic effect) when the culture medium (electrolyte) is disturbed by the alternating electric field $(50 \mathrm{~Hz}$ - linear regime and/ or deforming) [24].

It is established that the usual coated materials exhibit a limited resistance to the action of microorganisms, which has imposed the development of paints with antibacterial activity and low biodegradability, required for special applications (such as furniture and medical equipment) [35-37].

Taking into account these considerations, the aim of this paper consists in the experimental evaluation of the resistance to the action of molds of some usual painting materials aged by thermal cycling.

\section{Experiments part}

In order to assess the resistance to the action of mold of different origin paints, film samples were prepared from the investigated materials (table 1). 


\begin{tabular}{|c|c|c|c|}
\hline $\begin{array}{c}\text { Samples } \\
\text { code }\end{array}$ & Brand name & Resin type & Function \\
\hline \hline S1 & Sigmaprime $200[38]$ & Epoxy & Primer \\
\hline S2 & Sigmacover 456[39] & Modified epoxy & Topcoat \\
\hline S3 & Intergard 410[40] & Epoxy & Topcoat \\
\hline S4 & Hardtop [41] & Acrylic polyurethane & Topcoat \\
\hline S5 & Interthane $990[42]$ & Acrylic polyurethane & Topcoat \\
\hline S6 & Sigmadur 550H [43] & Polyurethane & Topcoat \\
\hline
\end{tabular}

Table 1

TESTED PAINTING MATERIALS
For obtaining the samples, the investigated paints were applied on a polyethylene substrate by brushing, and, after curing ( 7 days at $30 \pm 3^{\circ} \mathrm{C}$ ), dry films with thickness between 80 and 120im (measured with the micrometer) were detached.

Part of the obtained samples, were exposed to aging by 1000 successive thermal cycles (fig. 1) between $-38^{\circ} \mathrm{C}$ and $8^{\circ} \mathrm{C}$ in a VC 4018 , VOTSCH- Industrietechnik GmbH climatic chamber type, simulating the operating conditions (diurnal temperature variations).

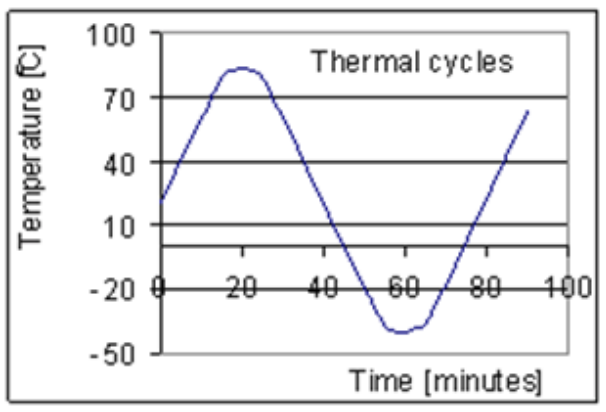

Fig. 1. Applied thermal cycles

In order to evaluate the comparative resistance to the action of molds, the paint films (control samples and samples exposed to thermal aging) were exposed according to [44-46] on saline gel culture media CzapekDox type $A$ (incomplete medium - without carbon source) or type $B$ respectively (complete medium - with sucrose, an easily assimilated carbon source).

The Czapek-Dox A culture medium was prepared by dissolving $2 \mathrm{~g}$ of sodium nitrate $\left(\mathrm{NaNO}_{3}\right), 0.7 \mathrm{~g}$ monopotassium phosphate ( $\mathrm{KH}_{2} \mathrm{PO}$ ), $0.3 \mathrm{~g}$ dipotassium phosphate $\left(\mathrm{K}_{2} \mathrm{HPO}_{4}\right), 0.5 \mathrm{~g}$ potassium chloride $(\mathrm{KCl}), 0.5 \mathrm{~g}$ Magnesium sulphate heptahydrate $\left(\mathrm{MgSO}_{4} \cdot 7 \mathrm{H}_{4} \mathrm{O}\right), 0.01 \mathrm{~g}$ iron (II) sulphate $\left(\mathrm{FeSO}_{4}\right)$ and $30 \mathrm{~g}$ agar-agar in $1000 \mathrm{~mL}$ of deionised water.

The Czapek-Dox $B$ culture medium was prepared by dissolving $30 \mathrm{~g}$ of sucrose in $1000 \mathrm{~mL}$ of Czapek-Dox $A$ medium.

The culture media with the samples of paint films were placed in Petri dishes with $060 \mathrm{~mm}$ and inoculated by spraying with a mixt solution of Alternaria alternata, Aspergillus flavus, Aspergillus niger, Aspergillus ustus, Cladosporium herbarum, Paecilomyces varioti, Penicillium citrinum, Penicillium funiculosum, Stachybotris atra and Trichoderma viride molds having about $10^{6} \mathrm{spores} / \mathrm{mL}$ salt solution. The prepared biological samples were incubated in an incubator with controlled atmosphere $\left(30 \pm 2^{\circ} \mathrm{C} ; \mathrm{RH}\right.$ $90 \pm 5 \%)$.

In order to establish the influence of the electric field applied to the culture medium, part of the samples were exposed in $50 \mathrm{~Hz}$ electrical field having the intensity of $5 \mathrm{~V} /$ $\mathrm{cm}$ [47] and applied between electrodes (Cu foil on TEXTOLIT substrate), connected to an adjustable homemade source of voltage $0.1 \mathrm{kV}-5 \mathrm{kV}-50 \mathrm{~Hz}$. (fig. 2).

Periodically, during incubation, the biological samples were analyzed and visually evaluated using a stereomicroscope (type IOR-Romania) and the coverage

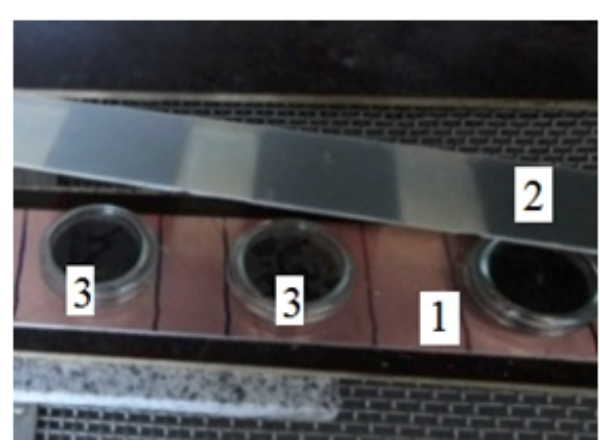

Fig. 2. The exposure of the microbiological samples (3) to controlled and homogeneous electric field between the electrode 1 (lower) and 2 (superior)

degree of the paint film was evaluated by approximation according to [45].

\section{Results and discussions}

The results of the microbiological observations performed on the samples unexposed to disturbing electric field on the culture media $A$ and $B$ with sucrose are presented in the table 2 and table 3 respectively.

By comparative analysis of the observations shown in table 2 and table 3 it is found that the molds growth on medium $A$ is delayed compared to that on medium $B$ indicating that the time needed to form the enzyme appliance necessary for the metabolism (LAG period) of food resources (carbon) from medium $B$ (with sucrose) is lower (with about $24 \mathrm{~h}$ ) than on medium $A$. From the ten species that are present in the mixed inoculum applied on the paintsamples, only the species Aspergillus niger (major presence in all samples), Trichoderma viride (present only in the samples on medium B) and Aspergillus flavus (present only on S1 - medium $B$ at 144 h of incubation) developed, ascertainmentexplained by the aggressiveness and the high capacity of adaptation of the species Aspergillus niger and Trichoderma viride respectively, making these species to become dominant. Due to their high capacity of accommodation, using the developed enzymatic device, these species may have a major contribution in the biodegradation and biodeterioration processes of the painting materials [3-5], generally of the polymeric materials with polyethylene [19, 48], polyurethanes $[49,50]$, etc.

The results of the microbiological observations in the samples exposed to an electrical field of $50 \mathrm{~Hz}$ and $5 \mathrm{~V} / \mathrm{cm}$ on culture medium $A$ are shown in table 4 and those on culture medium with sucrose (B) in table 5, respectively.

By comparing the observations from table 2 with those in table 4 and respectively the observations from table 3 with those in table 5 , it is found that under the action of $5 \mathrm{~V} /$ $\mathrm{cm} \& 50 \mathrm{~Hz}$ field, the growth of the mold Aspergillus niger is accelerated and stimulated both on $A$ and $B$ media and the $L A G$ periods are reduced with about $24 \mathrm{~h}$ respectively - a fact which is in a good agreement with the results reported in [25]. Also it is shown that only cultures of Aspergillus niger were grown on the samples exposed to 
Table 2

THE MICROBIOLOGICAL OBSERVATIONS ON "A" CULTURE MEDIUM- WITHOUT EXPOSURE TO ELECTRIC FIELD

\begin{tabular}{|c|c|c|c|c|c|c|c|c|}
\hline \multirow{2}{*}{\multicolumn{2}{|c|}{ Samples }} & \multicolumn{7}{|c|}{ Observations and incubation times } \\
\hline & & $\begin{array}{c}24 \\
\text { hours }\end{array}$ & $\begin{array}{c}48 \\
\text { hours }\end{array}$ & $\begin{array}{c}72 \\
\text { hours }\end{array}$ & & 144 hours & & 336 hours \\
\hline \multirow[b]{2}{*}{ S1 } & Initial & \multirow{12}{*}{ 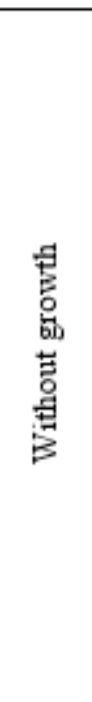 } & \multirow{12}{*}{ 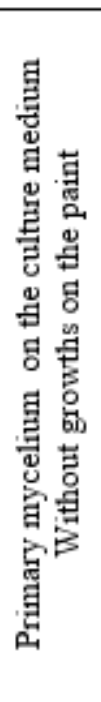 } & \multirow{12}{*}{ 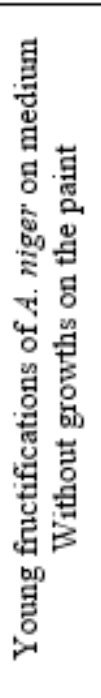 } & \multirow{12}{*}{ 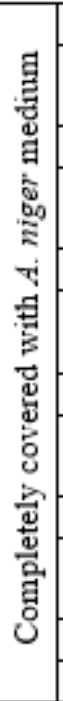 } & Without growth & \multirow{12}{*}{ 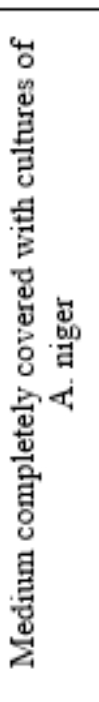 } & Without growth \\
\hline & Aged & & & & & Without growth & & $\begin{array}{c}\text { Rare young fructifications of } A \text {. } \\
\text { niger }\end{array}$ \\
\hline \multirow[b]{2}{*}{$\mathbf{S} 2$} & Initial & & & & & Without growth & & Without growth \\
\hline & Aged & & & & & Without growth & & $\begin{array}{c}\text { Rare young fructifications of } A . \\
\text { niger }\end{array}$ \\
\hline \multirow[b]{2}{*}{ S3 } & Initial & & & & & A. niger young fructifications & & A. niger young fructifications \\
\hline & Aged & & & & & $\begin{array}{l}\text { A. niger young and mature } \\
\text { fructifications }\end{array}$ & & $\begin{array}{l}\text { A. niger young and mature } \\
\text { fructifications }\end{array}$ \\
\hline \multirow[b]{2}{*}{ S4 } & Initial & & & & & A. niger young fructifications & & A. niger young fructifications \\
\hline & Aged & & & & & $\begin{array}{l}\text { A. niger young and mature } \\
\text { fructifications }\end{array}$ & & $\begin{array}{l}\text { A. niger young and mature } \\
\text { fructifications }\end{array}$ \\
\hline \multirow[b]{2}{*}{ S5 } & Initial & & & & & Without growth & & A. niger young fructifications \\
\hline & Aged & & & & & A. niger young fructifications & & $\begin{array}{l}\text { A. niger young and mature } \\
\text { fructifications }\end{array}$ \\
\hline \multirow{2}{*}{ S6 } & Initial & & & & & Without growth & & Without growth \\
\hline & Aged & & & & & Without growth & & Without growth \\
\hline
\end{tabular}

Table 3

THE MICROBIOLOGICAL OBSERVATIONS ON "B" CULTURE MEDIUM- WITHOUT EXPOSURE TO ELECTRIC FIELD

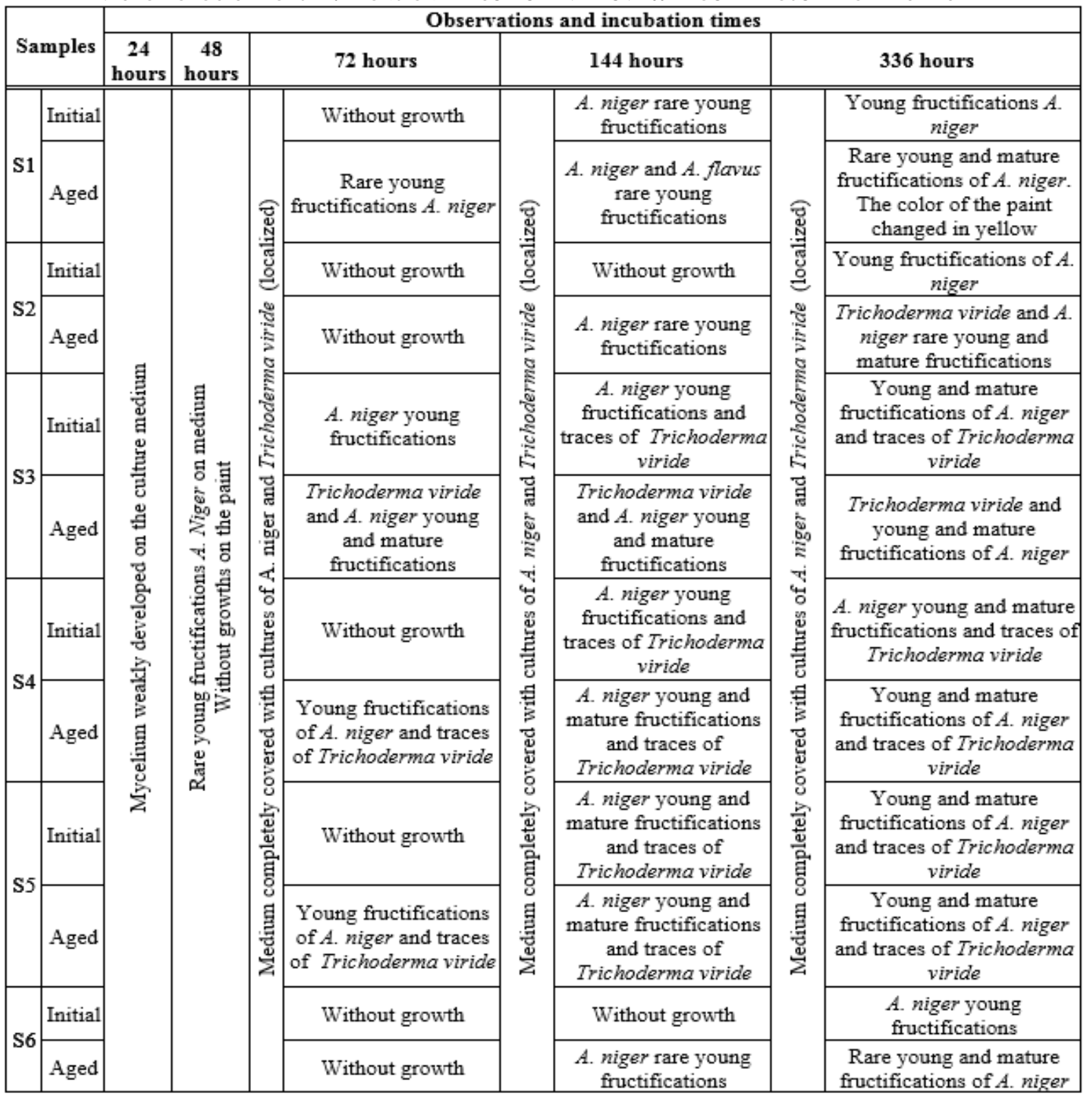


Table 4

THE MICROBIOLOGICAL OBSERVATIONS ON "A" CULTURE MEDIUM- EXPOSURE TO 50Hz, 5V/cm

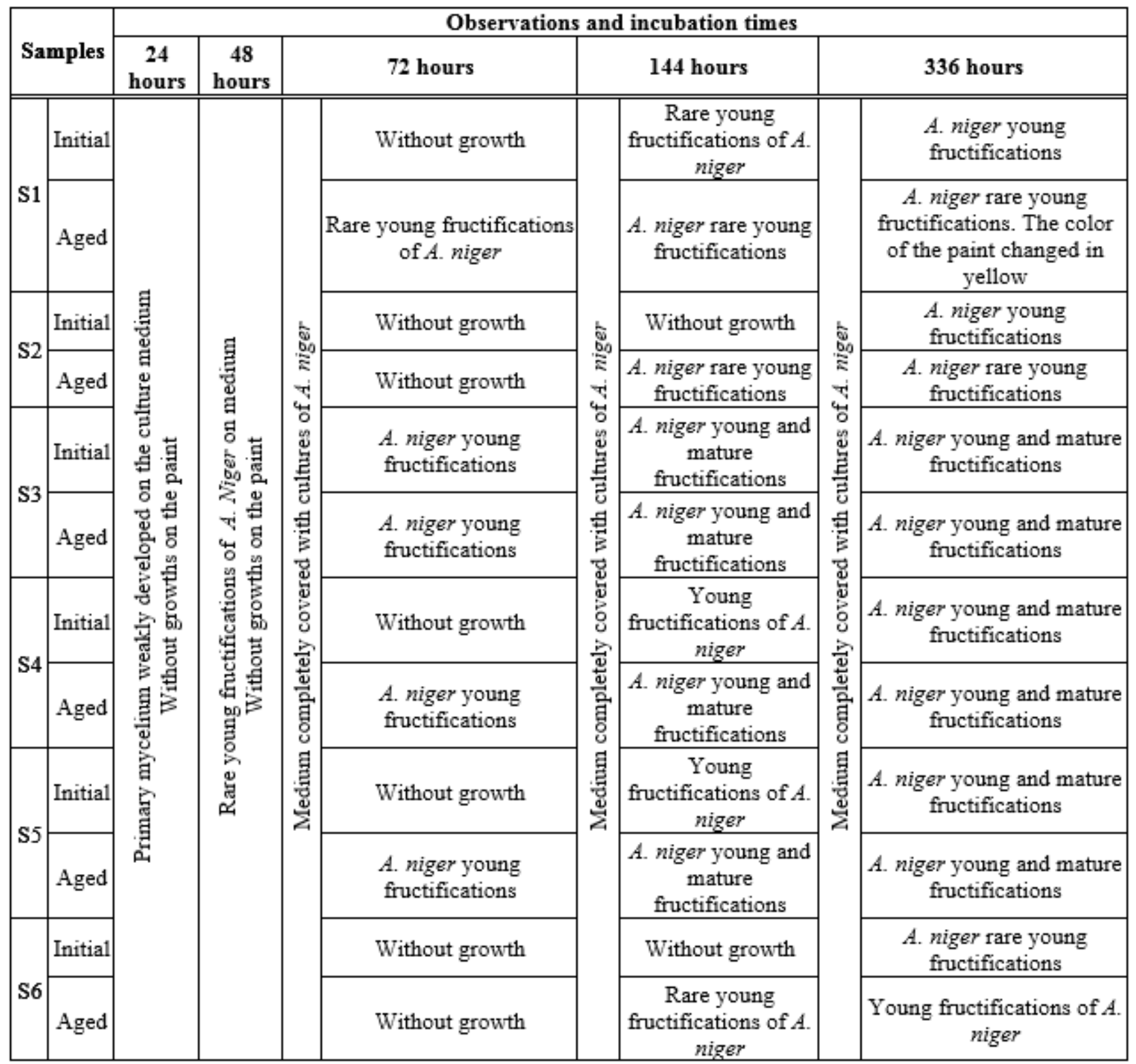

electrical field, the growth of Trichoderma viride and Aspergillus flavus being completely inhibited.

Figures 3- 9 show some representative images of the samples recorded during the microbiological observations.

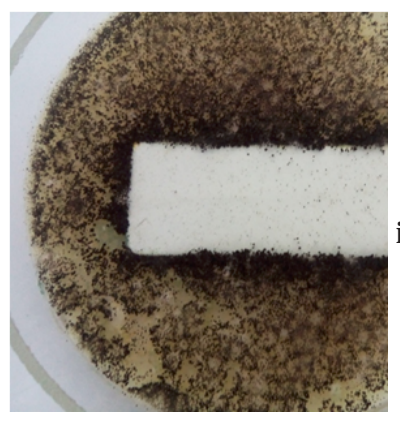

Fig. 3. Fungal growth on $\mathrm{S} 1$ aged sample - medium $B, 7$ days of incubation in electric field of $5 \mathrm{~V} / \mathrm{cm}$ $\& 50 \mathrm{~Hz}$ (rare young and mature fructifications of $A$. niger)

Taking into consideration the performed microbiological observations, it was found that the inhibition zones for the mold growth around the paint samples on the culture medium are not observed, (figs. 3, 4, 8 and 10), which indicate that the investigated materials do not contain toxic or xenobiotic materials. On the contrary, it was observed that on the edge of the mold samples, the mold grow th are more intense than on the culture media (especially in the case of medium A - fig. 10). This observation suggests that the enzymatic unit developed by mold [13] is able to metabolize the carbon from the polymeric structure of the investigated paints, in the places where the mineral resources are provided (medium Czapek-Dox). In this situation, the few and less developed mold growths on the paint samples can be explained by the limited mineral resources (only from the sprayed inoculum solution) and by the difficulty of the hyphae to penetrate the polymer paint. Thus, it can be explained also that after thermo oxidative degradation of the paint, the mold growths were more intense in all the samples aged by thermal cycling that simulate the operating climatic conditions $[6,7,9,51$, 52] than on the initial samples.

The evaluation results concerning the coverage degree of the paint samples with mold after $336 \mathrm{~h}$ of incubation and the qualification according to [45] are presented synthetically in the table 6.

By analyzing the data in table 6 , it is found that the resistance of the investigated paining materials to the action of molds is differentiated depending of their composition (origin). It is noted that, for all the samples aged by thermal cycling, the resistance to the action of molds is lower than for initial samples.

Analyzing the data in table 6 in correlation with the observations in tables 2-5 it is shown than on the samples exposed to electric field $(5 \mathrm{~V} / \mathrm{cm} \& 50 \mathrm{~Hz})$ the coverage of 
Table 5

THE MICROBIOLOGICAL OBSERVATIONS ON “B” CULTURE MEDIUM- EXPOSURE TO 50HZ, 5V/CM

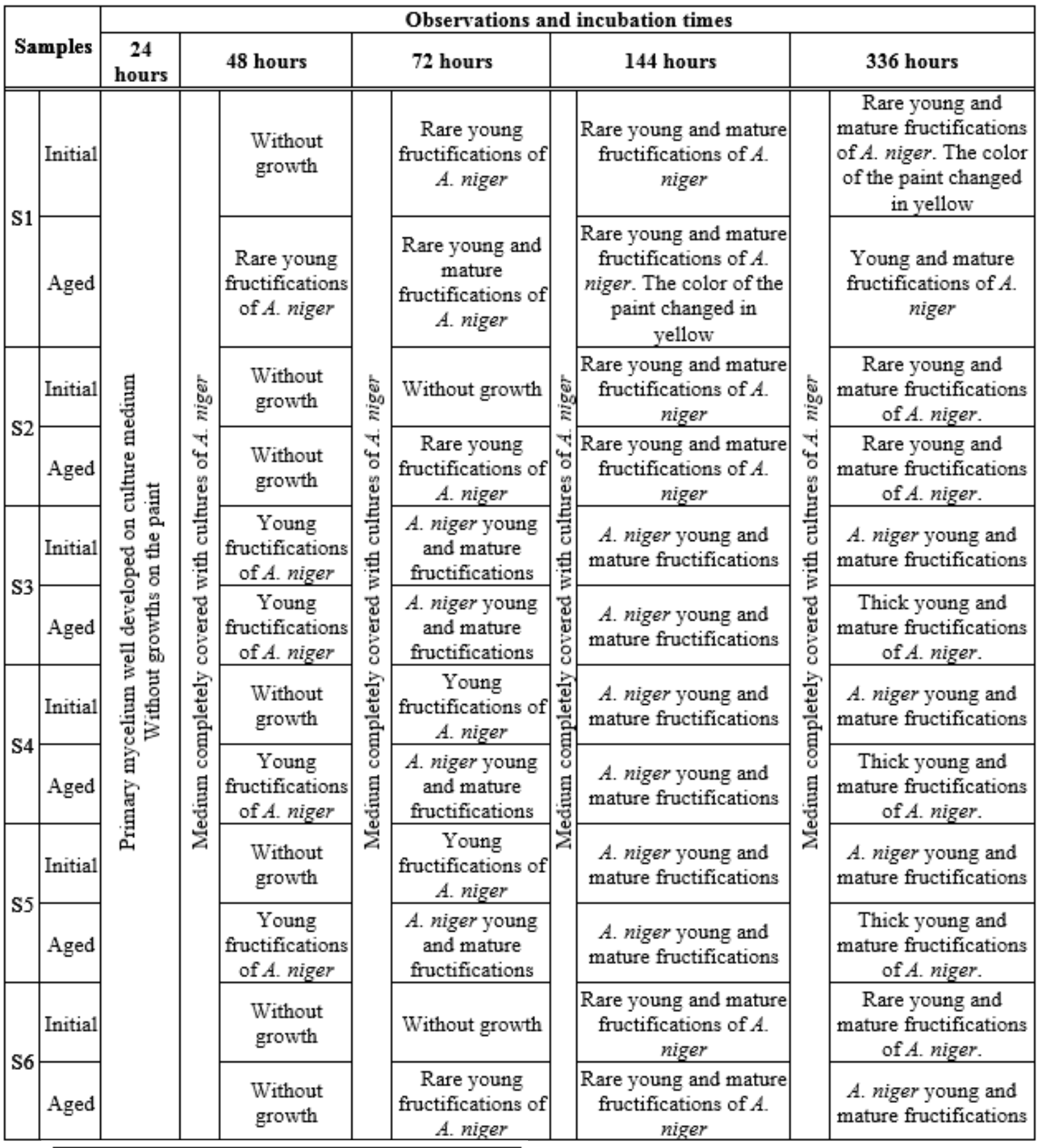

\begin{tabular}{|c|c|c|c|c|c|c|c|c|c|}
\hline \multirow{4}{*}{\multicolumn{2}{|c|}{$\begin{array}{c}\text { Paint } \\
\text { sample }\end{array}$}} & \multicolumn{8}{|c|}{ Degree of coverage $[\%]$ and $Q^{*}[45]$} \\
\hline & & \multicolumn{4}{|c|}{ "A" } & \multicolumn{4}{|c|}{ "B" } \\
\hline & & \multicolumn{2}{|c|}{$\begin{array}{l}\text { Without } \\
\text { electrical } \\
\text { field }\end{array}$} & \multicolumn{2}{|c|}{$\begin{array}{l}5 \mathrm{~V} / \mathrm{cm} \\
\& 50 \mathrm{~Hz}\end{array}$} & \multicolumn{2}{|c|}{$\begin{array}{c}\text { Without } \\
\text { electrical } \\
\text { field }\end{array}$} & \multicolumn{2}{|c|}{$\begin{array}{c}5 \mathrm{~V} / \mathrm{cm} \& \\
50 \mathrm{~Hz}\end{array}$} \\
\hline & & {$[\%]$} & $\mathrm{Q}^{*}$ & {$[\%]$} & $Q^{*}$ & {$[\%]$} & $\mathrm{Q}^{*}$ & {$[\%]$} & $Q^{*}$ \\
\hline \multirow[t]{2}{*}{$\mathrm{S} 1$} & initial & - & 0 & - & 1 & - & 1 & $2-3$ & 2 \\
\hline & aged & - & 1 & $2-3$ & 2 & $2-3$ & 2 & $5-6$ & 2 \\
\hline \multirow[t]{2}{*}{$\mathrm{S} 2$} & initial & - & 0 & - & 1 & - & $\mathbf{1}$ & $2-3$ & 2 \\
\hline & aged & - & 1 & $2-3$ & 2 & $2-3$ & 2 & $4-5$ & 2 \\
\hline \multirow[t]{2}{*}{ S3 } & initial & - & 1 & 10 & 2 & 15 & 2 & 30 & 3 \\
\hline & aged & $5-10$ & 2 & 20 & 2 & 30 & 3 & 60 & 4 \\
\hline \multirow[t]{2}{*}{ S4 } & initial & - & 1 & \begin{tabular}{|l}
$4-5$ \\
\end{tabular} & 2 & $5-6$ & 2 & 10 & 2 \\
\hline & aged & $2-3$ & 2 & $8-10$ & 2 & $8-10$ & 2 & 30 & 3 \\
\hline \multirow[t]{2}{*}{ S5 } & initial & - & 1 & $2-3$ & 2 & $6-8$ & 2 & 15 & 2 \\
\hline & aged & $2-3$ & 2 & \begin{tabular}{|l|}
$4-6$ \\
\end{tabular} & 2 & 15 & 2 & 30 & 3 \\
\hline \multirow[t]{2}{*}{ S6 } & initial & - & 0 & - & 1 & - & 1 & $2-3$ & 2 \\
\hline & aged & - & 0 & - & 1 & $2-3$ & 2 & $4-6$ & 2 \\
\hline
\end{tabular}

Table 6

THE COVERAGE DEGREE OF THE PAINT SAMPLES WITH MOLD AFTER

$336 \mathrm{~h}$ OF INCUBATION 


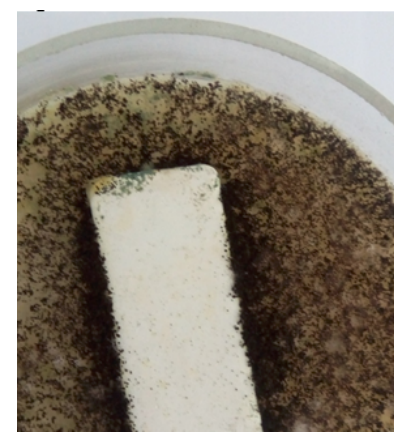

Fig. 4. Fungal growth on $\mathrm{S} 2$ aged sample- medium $B, 14$ incubation days with no electric field (Trichoderma viride and rare and mature fructifications of $A$. niger)

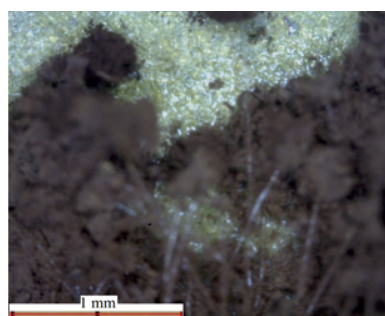

Fig. 5. Fungal growth on $\mathrm{S} 3$ aged sample- detail, medium $v, 14$ days of incubations in $5 \mathrm{~V} / \mathrm{cm} \& 50 \mathrm{~Hz}$ electric field
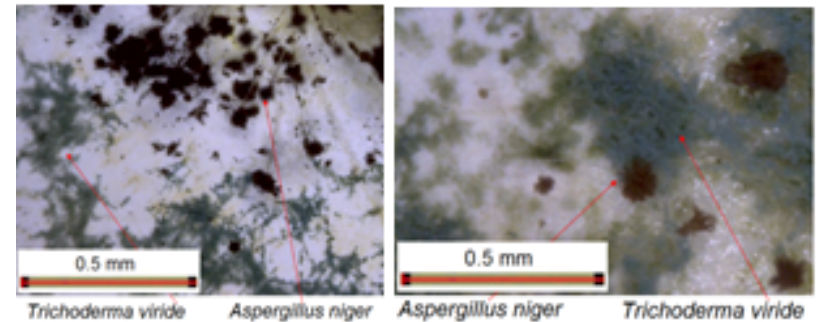

Fig. 6. Fungal growth on $\mathrm{S} 3$ aged sample - detail, medium $B, 7$ days of incubation with no electric field
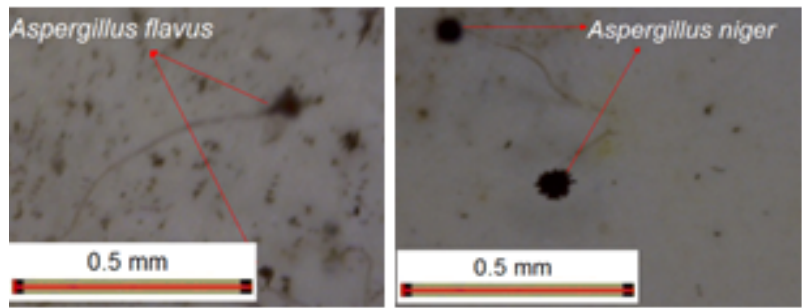

Fig. 7. Fungal growth on $\mathrm{S} 1$ aged sample - detail, medium $B, 7$ days of incubation with no electric field

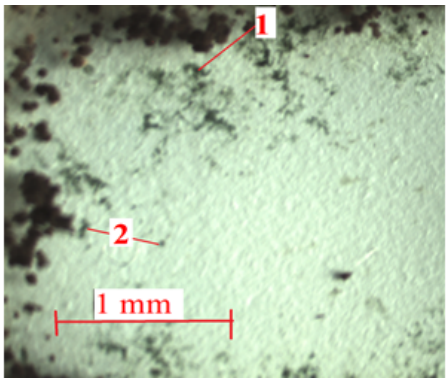

Fig. 8. Fungal growth on S3 aged sample - detail, medium "B", 3 days of incubation with no electric field

(1 - Trichoderma viride; 2 - A. niger)

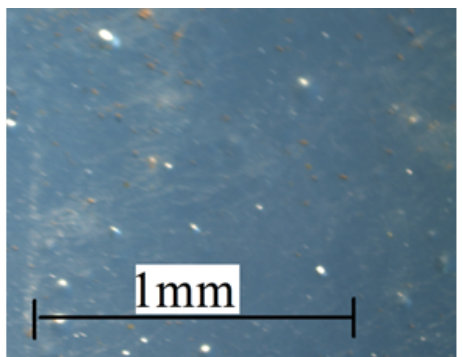

Fig. 9. Fungal growth on S5 aged sample - detail, medium $B, 3$ days of incubation in $5 \mathrm{~V} / \mathrm{cm} \& 50 \mathrm{~Hz}$ electric field ( $A$. niger young and mature fructifications).

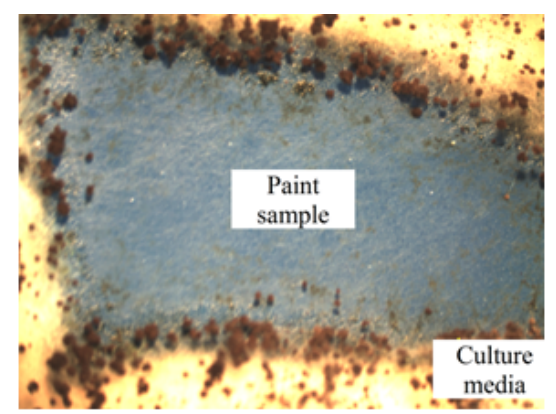

Fig. 10. Fungal growth on S5 initial sample detail, medium $A, 14$ days of incubation in $5 \mathrm{~V} / \mathrm{cm} \& 50 \mathrm{~Hz}$ electric field (A. niger young and mature

fructifications)

the paint samples with mold is about two times higher than for unexposed samples. This can explain the damages of the supporting pillars of high voltage power lines (exposed simultaneously both to weathering and electrical field [2]). Under the given experimental conditions, the lower resistance to the action of molds was recorded in samples S3 (on medium B, in an electrical field of $5 \mathrm{~V} / \mathrm{cm}$ $\& 50 \mathrm{~Hz}$; the coverage values were: initial about $30 \%$ coverage and for aged approx. $60 \%$ coverage. In the absence of electrical field the coverage values were: initial about $10 \%$ and for aged approx. $20 \%$.

\section{Conclusions}

By specific microbiological determinations carried out both on unexposed samples and on samples exposed to an electrical field of $5 \mathrm{~V} / \mathrm{cm} \& 50 \mathrm{~Hz}$ during incubation, the resistance to the action of molds of some paining materials aged by thermal cycling was evaluated comparatively. After performing the microbiological investigations and observations it was found that:

- the formation and growth of the mold colonies on the samples exposed to Czapek-Dox medium $B$ with sucrose has a higher rate than on sucrose-free medium $A$;

- in the absence of the electrical field applied to the samples during incubation, from the ten species present in the mixtinoculum applied by spraying only the following species were developed: Aspergillus niger (major - present in all samples), Trichoderma viride (presentonlyin samples on medium B) and Aspergillus flavus present only in S1 medium B to 144 incubation hours);

- the aging by applying thermal cycling reduces substantially (about 2 times) the resistance of the investigated coatings to the action of molds (the coverage areas become doubles);

- the field of $5 \mathrm{~V} / \mathrm{cm} \& 50 \mathrm{~Hz}$ stimulates the growth of Aspergillus niger, inhibits completely those of Trichoderma viride and Aspergillus flavus and reduces substantially (about 2 times) the resistance of the investigated paintings to the action of molds (the coverage of the samples with mold doubles).

Acknowledgment: This work was financially supported by the UEFISCDI of Romania, under the scientific Programme "NUCLEU 2016 - 2017", contractPN $16110211 / 2016$.

\section{References}

1. RUS T., CARAMITU A., MITREA S., LINGVAY I., IEEEXplore, DOI: 10.1109/DEMISEE.2016.7530466, 2016, pp. 60-65

2. OPRINA G., RUS T., LINGVAY D., CARAMITU A., MITREA S., Electrotehnicã, Electronicã, Automatizari (EEA), vol. 65, no. 1, 2017, pp. 81 - 87

3. NAKAJIMA-KAMBE T., SHIGENO-AKUTSU Y., NOMURA N., ONUMA F., NAKAHARA T., Appl. Microbiol. Biotechnol., vol. 51, 1999, pp. 134140

4. RAVIKUMAR H.R., RAO S.S., KARIGAR C.S., Indian J of Science and Technol., vol. 5, no. 1, 2012, pp. 1977-1987

5. SIVAN A., Curr. Opin. Biotechnol., vol. 22, 2011, pp. 422-426 
6. HU J., LI X., GAO J., ZHAO Q., Prog. Org. Coat., vol. 65, 2009, pp. 504-509

7. YANG X.F., TALLMANE D.E., BIERWAGEN G. P., CROLLB S.G., ROHLIKET S., Polym. Degrad. Stab., vol. 77, no. 1, 2002, pp. 103-109 8. JOHNSON B.W., MCINTYRE R., Prog. Org. Coat., vol. 27, no. 1, 1996. pp. $95-106$

9. HU J., LI X., GAO J., ZHAO Q., Mater. Design, vol. 30, 2009, pp. 15421547

10. ZHOU G., LI L-A, WANG S., J IA H., LI S., $15^{\text {th }}$ International Conference on Experimental Mechanics, Paper ref: 2954, 2012, pp. 1-6

11. LABUZEK S., NOWAK B., Polym. J., vol. 51, no. 1, 2006, pp. 27-32 12. NAKAJ IMA-KAMBE T., SHIGENO-AKUTSU Y., NOMURA N., ONUMA F., NAKAHARA T., Appl. Microbiol. Biotechnol., vol. 51, 1999, pp. 134140

13. LOREDO-TREVINO A., GUTIERREZ-SANCHEZ G, RODRÝGUEZHERRERA R., AGUILAR C. N., J. Polym. Environ., vol. 20, 2012, pp. 258-265

14. RUS, T., RADU, E., LINGVAY, I., LINGVAY, M., CIOBOTEA BARBU, O.C., CAMPUREANU, C., UPB Sci. Bull., Series B - in press

15. LINGVAY, I., OLLERER, K., LINGVAY, C., HOMAN, C., CIOGESCU, O., Rev. Chim. (Bucharest), 58, no.7, 2007, p.624

16. LINGVAY, I., GROZA C., COMANESCU, A., LINGVAY, C., CIOGESCU, 0., HOMAN, C., CIOBANU, I., Electrotehnica, Electronica, Automatizãri (EEA), vol 56, no. 4, 2008, pp.13-16

17. LINGVAY, J., GROZA, C., LINGVAY, C., CSUZI, I., Korrozios Figyelo, vol. 49, no. 3, 2009, pp. 31-37

18. SZATMARI I., LINGVAY M., VLADOI C., LINGVAY I., Electrotehnica, Electronica, Automatizãri (EEA), vol. 61, no. 4, 2013, pp. 48-55

19. SZATMARI I., LINGVAY M., TUDOSIE L., COJ OCARU A., LINGVAY I., Rev. Chim. (Bucharest), 66, no. 3, 2015, p. 304

20. MATEI, Gh., LINGVAY, D., SPAFIU, P.C., TUDOSIE, L.M., EEAElectrotehnica, Electronica, Automatizãri (EEA), vol. 64, no. 4, 2016, pp. 52-58

21. LINGVAY, I., VOINA, A., LINGVAY, C., MATEESCU, C., Rev. Roum. Sci. Tech. El., vol. 53, no.2 bis, 2008, pp. 95-112.

22. LINGVAY, I., LINGVAY, C., VOINA, A., Rev. Roum. Sci. Tech. El, vol. 53, no. 2 bis, 2008, pp.85-94

23. LINGVAY, J., Korrozios Figyelo, vol. 44, no. 2, 2004, pp. 49-56

24. LINGVAY, I., RUS, G., STOIAN, F., LINGVAY, C., UPB Sci. Bull, Series

B, vol. 63, no.3, 2001, pp. 263-270

25. RADU, E., LIPCINSKI, D., TANASE, N., LINGVAY, I, Electrotehnica, Electronica, Automatizãri (EEA), vol. 63, no. 3, 2015, pp. 68-74

26. STANCU C., LINGVAY M., SZATMARI I., LINGVAY I., The $8^{\text {th }}$ International Symposium on Advanced Topics in Electrical Engineering, IEEExplore, DOI: 10.1109/ATEE.2013.6563449 , 2013, pp. $1-4$

27. SANDU D., LINGVAY I., LANYI S., MICU D.D., POPESCU C.L., BREM J., BENCZE L.C., PAISZ C., Studia Universitatis Babes-Bolyai, Chemia, vol. 54, no. 4, 2009, pp.195-201

28. LINGVAY M., STANCU C., SZATMARI I., LINGVAY I., Electrotehnica, Electronica, Automatica (EEA), vol. 61, no.1, 2013, pp. 43- 47
29. VOINA A., RADU E., CARAMITU A.R., LINGVAY M., ALECU G., J ournal of Sustainable Energy (JSE), vol. 7, no. 2, 2016, pp. 62 - 66

30. SZATMARI I., TUDOSIE L.M., COJOCARU A., LINGVAY, M., PRIOTEASA, P., VISAN, T., U.P.B. Sci. Bull., Series B, vol. 77, no. 3, 2015, pp. 91 - 102

31. LINGVAY J., SZATMARI I., PRIOTEASA P., LINGVAY M., TUDOSIE L. M., Korrozios Figyelo, vol. 54, no. 1, 2014, pp. 15-21

32. LINGVAY I., RUS G., BURUNTEA N., in UPB Sci. Bull, Series B, vol. 63, no. 3, 2001, pp. 29-36

33. RADU E., MITREA S., PATROI D., VOINA A., MOSCALIUC H., LINGVAY I., IEEEXplore, DOI: 10.1109/DEMISEE.2016.7530483, 2016, pp. 38-43 34. PRIOTEASA P., LINGVAY M., SZATMAARI I., BURUNPEA N., LINGVAY I., Electrotehnica, Electronica, Automatica (EEA), vol. 62, no. 2, 2014. pp. 60-65

35. PICA, A., FICAI, A., FICAI, D., GURAN, C., DUMITRU, F., UPB Sci. Bull., Series B, vol. 77, no. 3, 2015, pp. 115-130

36. PICA, A., GURAN C., FICAI D., FICAI A., OPREA O., UPB Sci. Bull., Series $B$, vol. 75, no. 1, 2013, pp. 35-42

37. PICA, A., FICAI, A., Rev. Chim. (Bucharest), 67, no. 1, 2016, p. 34 38.***Sigmaprime200:http://w w w.ppgpmc.com/Products/7416/ SIGMAPRIME-200-SERIES.aspx

39.*** Sigmacover 456: http://www.ppgpmc.com/Products/7466/ SIGMACOVER-456.aspx

40. ***Intergard 410: http://www.international-marine.com/products/ info/intergard-410.aspx

41.*** Hardtop:http://www.jotun.com/Datasheets/Download?url=\%2 FTDS\%2FTDS_449_Hardtop+AS_Euk_GB.pdf

42. *** Interthane 990: http://www.international-pc.com/products/info/ Finishes/Interthane-990.aspx

43. *** Sigmadur 550H: http://www.ppgpmc.com/Products/7537/ SIGMADUR-550.aspx

44. *** SR EN 60068-2-10/2006 Environmental testing. Tests. TestJ and guidance: Mould growth

45.*** SR EN ISO846/2000, Plastics - Evaluation of the action of microorganisms

46. *** BS 3900-G6:1989 - Methods of test for paints. Assessment of resistance to fungal growth

47. LINGVAY, M., CZUMBIL, L., Electronica, Electrotehnica, Automatica (EEA), vol. 63, no. 3, 2014, pp. 84-89

48. NOWAK B., PAJYK J., DROZD-BRATKOWICZ M., RYMARZ G., Int. Biodeter. \& Biodegr. vol. 65, no. 6, 2011. pp. 757-767

49. CANGEMI J.M., DOS SANTOS A.M., NETO S.C., CHIERICE G.O., Polimeros, vol. 18, no. 3, 2008, pp. 201-206

50. HOWARD G.T., Recent Developments in Polymer Recycling, Editors: A. Fainleib and 0.Grigoryeva, 2011, pp. 215-238

51. HUA J., LI X., GAO J., ZHAO Q., Mater. Des, vol. 30, 2009, pp. 15421547

52. GULMINE J.V, J ANISSEK PR, HEISE HM, AKCELURD L, Polym Degrad Stabil, vol 79, 2003, pp. 385-397

Manuscript received: 21.12 .2016 